\title{
PENGGUNAAN ABU DASAR BATUBARA SEBAGAI PENGGANTI SEBAGIAN AGREGAT HALUS PADA CAMPURAN LATASIR B TERHADAP KARAKTERISTIK MARSHALL
}

\section{Basic Use of Coal Ash to Replace Some Fine Aggregate on Characteristics of Mixed Latasir B Marshall}

\author{
Roza Gusman $^{1}$ \& Alik Ansyori ${ }^{2}$ \\ 1,2Jurusan Teknik Sipil Fakultas Teknik - Universitas Muhammadiyah Malang \\ Alamat korespondensi : Jalan Raya Tlogomas 246 Malang 65144
}

\begin{abstract}
Coal bottom ash is the residue from the burning of coal in thermal power plants. The use of coal bottom ash as an alternative material mix pavement is one way to take advantage of these residues. This study aimed to determine the effect of the use and the quantity of coal bottom ash as partial replacement of fine aggregate characteristics that meet the requirements for mixed marshall latasir B. Partial replacement of fine aggregate with coal bottom ash is made with a variation of $5 \%$, $10 \%, 15 \%, 20 \%, 25 \%, 30 \%$, and $35 \%$ of the total proportion of fine aggregate. Results of the study note that the use of coal bottom ash generally improves the quality mix latasir B. Latasir mixture $B$ which has the characteristics of the best marshal is on the basis of coal ash content of 17.2\%.
\end{abstract}

Keywords: latasir B asphalt mixtures, coal bottom ash, marshall characteristics.

\begin{abstract}
Abstrak
Bottom ash batubara adalah residu dari pembakaran batubara di pembangkit listrik termal . Penggunaan batubara bawah abu sebagai alternatif campuran bahan perkerasan adalah salah satu cara untuk mengambil keuntungan dari residu tersebut. Penelitian ini bertujuan untuk mengetahui pengaruh penggunaan dan kuantitas bawah abu batubara sebagai pengganti parsial karakteristik agregat halus yang memenuhi persyaratan untuk campuran marshall latasir B. pengganti parsial agregat halus dengan bottom ash batubara dibuat dengan variasi $5 \%, 10 \%, 15 \%, 20 \%, 25 \%, 30 \%$, dan 35 $\%$ dari total proporsi agregat halus . Hasil penelitian mencatat bahwa penggunaan bottom ash batubara umumnya meningkatkan kualitas campuran latasir B. Latasir campuran B yang memiliki karakteristik marshal terbaik adalah berdasarkan kadar abu batubara dari $17,2 \%$.
\end{abstract}

Kata kunci : campuran aspal B latasir, bawah batubara abu , karakteristik marshall .

\section{PENDAHULUAN}

Campuran Aspal Latasir (lapis tipis aspal pasir) ditujukan untuk jalan-jalan dengan lalu lintas ringan, khususnya pada daerah dimana agregat kasar tidak tersedia dan untuk perbaikan jalan seperti pelapisan ulang jalan (overlay). Pemilihan akan tergantung utamanya pada gradasi pasir yang digunakan. Campuran aspal latasir mempunyai ketahanan alur (rutting) yang rendah oleh sebab itu tidak boleh digunakan pada lapisan yang tebal, pada jalan-jalan dengan lalu lintas berat dan pada daerah tanjakan (Muhammad, 2012).

Abu dasar batubara (bottom ash) merupakan bahan buangan dari proses pembakaran batubara pada pembangkit tenaga yang mempunyai ukuran partikel lebih besar dan lebih berat dari pada abu terbang (fly ash). Abu dasar batubara akan jatuh pada dasar tungku pembakaran (boiler) dan terkumpul pada penampung debu (ash hopper) lalu dikeluarkan dari tungku dengan cara disemprot dengan air untuk kemudian dibuang di landfill atau ditumpuk begitu saja di dalam area industri. Penggunaan batubara sebagai bahan bakar di PT. Molindo Raya Industrial mempunyai konsekuensi penanganan abu batubara dalam jumlah yang sangat besar (Patrick, 2003).

Patrick (2003), telah melakukan studi dengan menguji efek pemakaian abu dasar batubara sebagai pengganti agregat halus menemukan bahwa 
persentase terbaik penggantian agregat halus dengan abu dasar batubara adalah $10 \%$.

Tujuan penelitian ini adalah Untuk mengetahui pengaruh penggantian sebagian agregat halus dengan abu dasar batubara terhadap karakteristik marshall pada campuran latasir B dan untuk mengetahui kadar abu dasar batubara optimum yang di dapat pada penggantian sebagian agregat

halus dengan abu dasar batubara yang memenuhi karakteristik marshall.

\section{METODE PENELITIAN}

Studi dilaksanakan di laboratorium Jalan Raya Teknik Sipil Universitas Muhammadiyah Malang. Adapun tahapan studi, disajikan sebagaimana pada gambar 1.

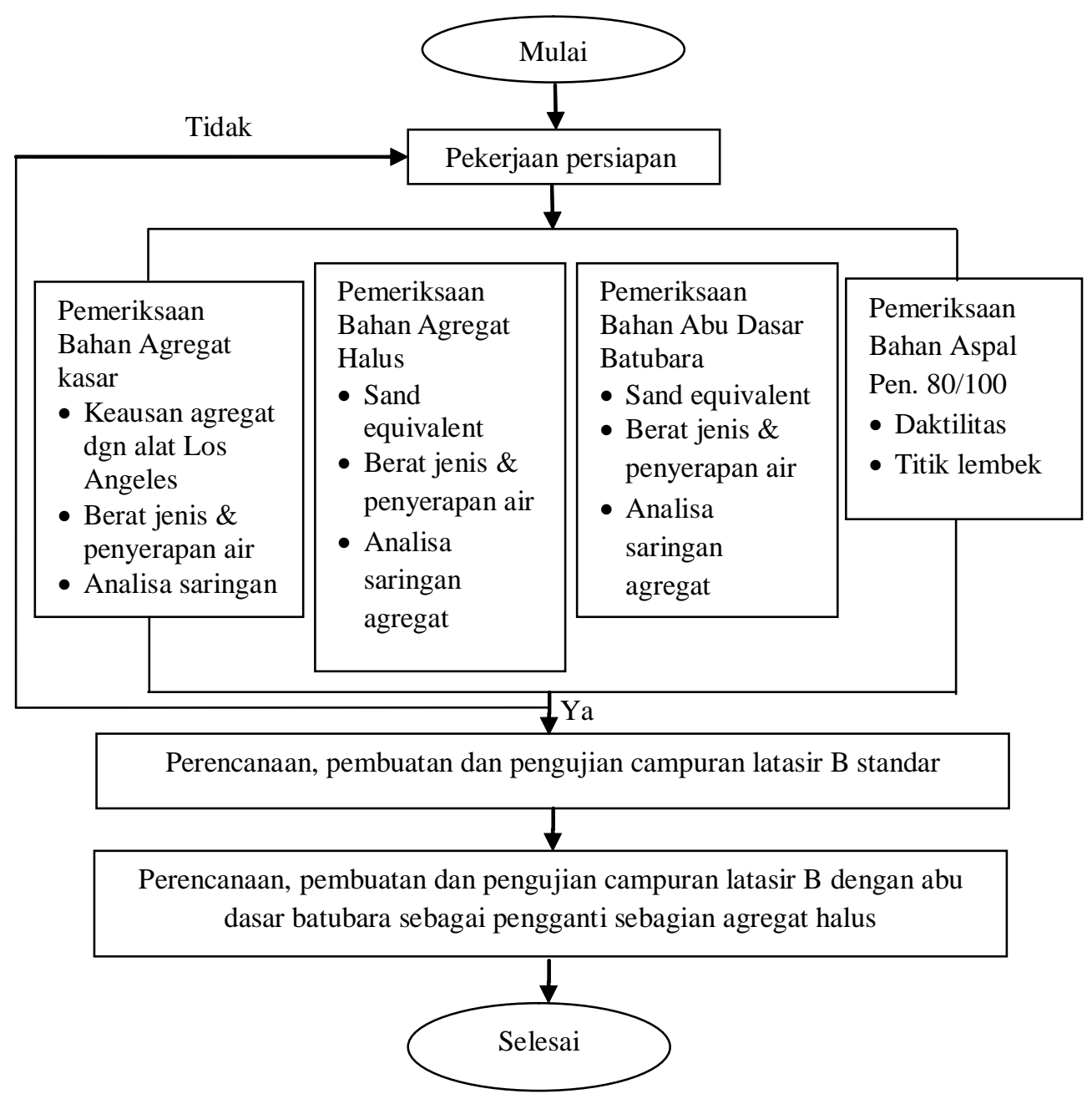

Gambar 1. Diagram Alur Tahapan Studi

Material yang digunakan adalah: (a) kerikil (batu pecah) dan abu batu diperoleh dari pabrik pemecah batu Oma Campus, Kecamatan Dau, Kabupaten Malang; (b) pasir alam diperoleh dari sungai Brantas Kelurahan Tlogomas, Kecamatan Lowokwaru, Kabupaten Malang; (c) abu dasar batubara diperoleh dari PT. Molindo Raya Industrial di Lawang, Kab. Malang; (d) Filler yang digunakan adalah Portland Cement (PC) merek Semen Gresik; (e) aspal yang digunakan adalah jenis aspal padat dengan penetrasi 80-100.

Peralatan menggunakan standar pemeriksaan, perencanaan serta pengujian campuran aspal panas di laboratorium Jalan Raya Teknik Sipil Universitas Muhammadiyah Malang.

Perencanaan campuran bertujuan untuk mendapatkan resep campuran, Dengan langkahlangkah meliputi: pemilihan dan penentuan sifat agregat; penentuan campuran nominal; penentuan proporsi campuran; membuat benda uji. Campuran latasir B standar diperiksa dengan alat Marshall (Marshall Test). Dengan tujuan untuk mendapatkan nilai stabilitas dan flow. Hubungan antara kadar aspal dan nilai karakteristik Marshall divisualisasikan dalam bentuk grafik selanjutnya digunakan untuk mendapatkan Kadar Aspal Optimum. 


\section{Campuran Latasir B dengan Abu Dasar Batubara}

Berdasarkan kadar aspal optimum pada campuran latasir B standar, maka campuran latasir B dengan abu dasar batubara dilakukan dengan mengganti sebagian agregat halus dengan abu dasar batubara secara bervariasi: 5\%, 10\%, 15\%, $20 \%, 25 \%, 30 \%$ dan $35 \%$.

Untuk mengetahui nilai karakteristik Marshall campuran latasir B dengan abu dasar batubara sebagai pengganti sebagian agregat halus diperiksa dengan alat Marshall (Marshall Test). Hubungan antara kadar abu dasar batubara dan nilai karakteristik marshall divisualisasikan dalam bentuk grafik, selanjutnya digunakan untuk mendapatkan kadar abu dasar batubara optimum dari campuran latasir B dengan abu dasar batubara sebagai pengganti sebagian agregat halus.

\section{HASIL DAN PEMBAHASAN}

\section{Pemeriksaan Bahan}

Hasil pemeriksaan agregat kasar (batu pecah) dan agregat halus (pasir alam, abu batu dan abu dasar batubara disajikan pada tabel 1 dan tabel 2 .

Tabel 1. Hasil Pemeriksaan Agregat Kasar

\begin{tabular}{lcc}
\hline \multicolumn{1}{c}{ Jenis Pemeriksaan } & \multicolumn{1}{c}{ Syarat } & Hasil \\
\hline Keausan agregat kasar & Max 40\% & $26,68 \%$ \\
Berat jenis bulk (atas dasar kering oven) & Min 2.5gr/cm & $2,59 \mathrm{gr} / \mathrm{cm}^{3}$ \\
Berat jenis bulk (atas dasar kering permukaan) & Min 2.5gr/cm & $2,65 \mathrm{gr} / \mathrm{cm}^{3}$ \\
Berat jenis semu & Min2.5gr/cm & $2,76 \mathrm{gr} / \mathrm{cm}^{3}$ \\
Penyerapan air & Max 3\% & $2,41 \%$ \\
Analisa saringan & & \\
- Gradasi lolos $1 / 2$ & $95 \%-100 \%$ & $96,22 \%$ \\
- Gradasi lolos $3 / 8$ & $50 \%-100 \%$ & $53,72 \%$ \\
- Gradasi lolos no.4 & $0 \%-50 \%$ & $18,96 \%$ \\
- Gradasi lolos no.200 & $0 \%-5 \%$ & $1,16 \%$ \\
\hline
\end{tabular}

Tabel 2. Hasil Pemeriksaan Agregat Halus

\begin{tabular}{|c|c|c|c|c|}
\hline Jenis Pemeriksaan & Syarat & $\begin{array}{l}\text { Pasir } \\
\text { Alam }\end{array}$ & $\begin{array}{l}\text { Abu } \\
\text { Batu }\end{array}$ & $\begin{array}{c}\text { Abu Dasar } \\
\text { Batubara }\end{array}$ \\
\hline Nilai Sand Equivalent (SE) (\%) & Min 50 & 80,85 & 91,10 & 78,69 \\
\hline $\begin{array}{l}\text { Berat jenis bulk (atas dasar kering oven) } \\
\left(\mathrm{gr} / \mathrm{cm}^{3}\right)\end{array}$ & Min 2.5 & 2,65 & 2,66 & 2,66 \\
\hline $\begin{array}{l}\text { Berat jenis bulk (atas dasar kering permukaan) } \\
(\mathrm{gr} / \mathrm{cm})\end{array}$ & Min 2.5 & 2,70 & 2,70 & 2,67 \\
\hline Berat jenis semu $\left(\mathrm{gr} / \mathrm{cm}^{3}\right)$ & $\operatorname{Min} 2.5$ & 2,80 & 2,78 & 2,70 \\
\hline Penyerapan air (\%) & Max 3 & 1,83 & 1,63 & 0,5 \\
\hline \multicolumn{5}{|l|}{ Analisa saringan $(\%)$} \\
\hline - Gradasi lolos \#4 & $72-100$ & 98,20 & 95,60 & 95,33 \\
\hline - Gradasi lolos \#8 & $72-100$ & 91,93 & 73,80 & 76,57 \\
\hline - Gradasi lolos \#30 & $25-100$ & 39,00 & 26,53 & 27,03 \\
\hline - Gradasi lolos \#200 & $0-8$ & 3,13 & 3,27 & 5,30 \\
\hline
\end{tabular}

Berdasarkan analisa saringan agregat halus (grafik analisa saringan), diketahui bahwa perbandingan antara pasir alam : abu batu adalah $45 \%: 55 \%$.

Hasil pemeriksaan aspal dengan penetrasi 80/ 100 memiliki kualitas: titik lembek $48.25^{\circ} \mathrm{C}$; titik nyala $318^{\circ} \mathrm{C}$; titik bakar $332^{\circ} \mathrm{C}$; dan daktilitas 115 $\mathrm{cm}$.

\section{Campuran Latasir B Standar}

Campuran latasir B standar direncanakan dengan berdasar pada hasil pemeriksaan bahanbahan yang meliputi: analisa saringan agregat kasar dan agregat halus (abu batu \& pasir alam), pemeriksaan berat jenis \& penyerapan agregat kasar dan agregat halus.

Sifat-sifat agregat campuran latasir B standar disajikan pada tabel 3 . 
Tabel 3. Ringkasan Sifat-Sifat Agregat

\begin{tabular}{ccccccc}
\hline $\begin{array}{c}\text { Agregat } \\
\text { yang tersedia }\end{array}$ & \multicolumn{2}{c}{ Gradasi lolos ayakan } & \multicolumn{3}{c}{ Berat jenis } & $\begin{array}{c}\text { Absorbsi } \\
\text { air }(\%)\end{array}$ \\
\cline { 2 - 6 } & $\# 8$ & $\# 200$ & $\begin{array}{c}\text { Kering } \\
\text { oven }\end{array}$ & SSD & Semu & \\
\hline batu pecah & 4.20 & 1.16 & 2.59 & 2.65 & 2.76 & 2.41 \\
abu batu & 73.80 & 3.27 & 2.66 & 2.70 & 2.78 & 1.63 \\
pasir alam & 91.93 & 3.13 & 2.65 & 2.70 & 2.80 & 1.83 \\
\hline
\end{tabular}

\section{Campuran Nominal Latasir B Standar}

Campuran nominal untuk Latasir B standar direncanakan mengacu pada batas-batas komposisi fraksi rencana campuran dan persyaratan sifat campuran, Penentuan campuran nominal yang dimaksudkan adalah: fraksi agregat kasar $(\mathrm{CA})=$ 23.00\%; fraksi agregat halus $(\mathrm{FA})=55.10 \%$; fraksi bahan pengisi $(\mathrm{FF})=13.00 \%$; kadar aspal $(\mathrm{b})=$ $8.90 \%$.

Dengan mengacu pada fraksi-fraksi agregat dihasilkan persamaan matematika dan dengan analisa metode matriks didapat rancangan campuran nominal: batu pecah $11.08 \%$; abu batu $37.46 \%$; pasir alam $31.91 \%$; bahan pengisi $10.65 \%$; dan kadar aspal $8.9 \%$.

Kadar aspal campuran nominal, ditentukan dengan penyesuaian terhadap absorbs air oleh agregat dengan rancangan campuran nominal, sehingga kadar aspal campuran nominal dipilih 8.9\%. Dengan demikian proporsi campuran nominal latasir B standar yang disesuaikan, disajikan pada tabel 4. Sedangkan Proporsi campuran agregat latasir B Standar disajikan pada tabel 5. Serta gradasi agregat kombinasi dan luas permukaan agregat total latasir B standar disajikan pada table 6.

Tabel 4. Penyesuaian Proporsi Campuran Nominal Latasir B Standar

\begin{tabular}{|c|c|c|c|c|c|c|c|c|}
\hline \multirow{2}{*}{ MATERIAL } & \multirow{2}{*}{$\begin{array}{c}\text { Campuran } \\
\text { Nominal } \\
\text { Perhitunga } \\
\mathrm{n}\end{array}$} & \multicolumn{7}{|c|}{ Campuran Nominal Disesuaikan } \\
\hline & & 1 & 2 & 3 & 4 & 5 & 6 & 7 \\
\hline Batu Pecah & 11.08 & 11.08 & 11.08 & 11.08 & 11.08 & 11.08 & 11.08 & 11.08 \\
\hline Abu Batu & 37.46 & 38.96 & 38.46 & 37.96 & 37.46 & 36.96 & 36.46 & 35.96 \\
\hline Pasir Alam & 31.91 & 33.41 & 32.91 & 32.41 & 31.91 & 31.41 & 30.91 & 30.41 \\
\hline Bahan Pengisi & 10.65 & 10.65 & 10.65 & 10.65 & 10.65 & 10.65 & 10.65 & 10.65 \\
\hline Aspal ( A ) & 8.90 & 5.90 & 6.90 & 7.90 & 8.90 & 9.90 & 10.90 & 11.90 \\
\hline \multirow[t]{2}{*}{ TOTAL } & 100.00 & 100.0 & 100.0 & 100.0 & 100.0 & 100.0 & 100.0 & 100.0 \\
\hline & & 0 & 0 & 0 & 0 & 0 & 0 & 0 \\
\hline
\end{tabular}

Tabel 5. Proporsi Campuran Agregat Latasir B Standar

\begin{tabular}{|c|c|c|c|c|c|c|c|}
\hline \multirow{2}{*}{ MATERIAL } & \multicolumn{7}{|c|}{ Proporsi Campuran Agregat (\%) } \\
\hline & 1 & 2 & 3 & 4 & 5 & 6 & 7 \\
\hline Batu Pecah & 11.77 & 11.90 & 12.03 & 12.16 & 12.29 & 12.43 & 12.57 \\
\hline Abu Batu & 41.41 & 41.31 & 41.22 & 41.12 & 41.02 & 40.92 & 40.82 \\
\hline Pasir Alam & 35.51 & 35.35 & 35.19 & 35.03 & 34.86 & 34.70 & 34.52 \\
\hline Bahan Pengisi & 11.32 & 11.44 & 11.56 & 11.69 & 11.82 & 11.95 & 12.09 \\
\hline TOTAL & 100.00 & 100.00 & 100.00 & 100.00 & 100.00 & 100.00 & 100.00 \\
\hline
\end{tabular}

Tabel 6. Gradasi Agregat Kombinasi Dan Luas Total Permukaan Campuran Latasir B Standar

\begin{tabular}{|c|c|c|c|c|c|c|c|c|c|c|c|c|}
\hline \multirow{2}{*}{$\begin{array}{c}\text { Saringan } \\
\text { ASTM }\end{array}$} & \multicolumn{4}{|c|}{ Gradasi Agregat } & \multicolumn{7}{|c|}{ Gradasi Agregat Kombinasi } & \multirow{2}{*}{$\begin{array}{c}\text { Faktor } \\
\text { Permuka } \\
\text { an } \\
\text { Agegat }\end{array}$} \\
\hline & $\mathrm{a}$ & $\mathrm{b}$ & $\mathrm{c}$ & $\mathrm{d}$ & $\mathrm{I}$ & II & III & IV & $\mathrm{V}$ & VI & VII & \\
\hline $1 “$ & 100 & 100 & 100 & 100 & 100 & 100 & 100 & 100 & 100 & 100 & 100 & 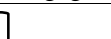 \\
\hline $3 / 4 *$ & 100 & 100 & 100 & 100 & 100 & 100 & 100 & 100 & 100 & 100 & 100 & \\
\hline $1 / 2 “$ & 96.22 & 100 & 100 & 100 & 99.56 & 99.55 & 99.55 & 99.54 & 99.54 & 99.53 & 99.52 & $-1 \times 0.41$ \\
\hline $3 / 8 “$ & 53.72 & 100 & 100 & 100 & 94.55 & 94.49 & 94.43 & 94.37 & 94.31 & 94.25 & 94.18 & \\
\hline \# 4 & 18.96 & 95.60 & 98.20 & 100 & 88.00 & 87.91 & 87.81 & 87.71 & 87.61 & 87.50 & 87.39 & $\times 0.41$ \\
\hline$\# 8$ & 4.20 & 73.80 & 91.93 & 100 & 75.01 & 74.93 & 74.84 & 74.75 & 74.66 & 74.57 & 74.48 & $\times 0.82$ \\
\hline
\end{tabular}




\begin{tabular}{|c|c|c|c|c|c|c|c|c|c|c|c|c|}
\hline$\# 16$ & 3.36 & 52.47 & 79.93 & 100 & 61.82 & 61.77 & 61.72 & 61.67 & 61.62 & 61.57 & 61.52 & $\times 1.64$ \\
\hline$\# 30$ & 2.92 & 26.53 & 39.00 & 100 & 36.49 & 36.53 & 36.57 & 36.62 & 36.66 & 36.70 & 36.75 & $\times 2.87$ \\
\hline \# 50 & 2.56 & 16.07 & 18.87 & 100 & 24.97 & 25.05 & 25.13 & 25.22 & 25.30 & 25.39 & 25.48 & $\times 6.14$ \\
\hline$\# 100$ & 2.16 & 8.80 & 7.60 & 100 & 17.91 & 18.02 & 18.12 & 18.23 & 18.34 & 18.46 & 18.57 & $\times 12.29$ \\
\hline \# 200 & 1.16 & 3.27 & 3.13 & 100 & 13.92 & 14.03 & 14.15 & 14.27 & 14.39 & 14.52 & 14.65 & $\times 32.27$ \\
\hline Perbandingan & \multicolumn{4}{|c|}{ a. Agregat Kasar } & 11.77 & 11.90 & 12.03 & 12.16 & 12.29 & 12.43 & 12.57 & \\
\hline Camp. & \multicolumn{4}{|c|}{ b. Abu Batu } & 41.41 & 41.31 & 41.22 & 41.12 & 41.02 & 40.92 & 40.82 & \\
\hline Agregat $(\%$ & \multicolumn{4}{|c|}{ c. Pasir } & 35.51 & 35.35 & 35.19 & 35.03 & 34.86 & 34.70 & 34.52 & \\
\hline $\begin{array}{l}\text { Berat Total } \\
\text { Agregat) }\end{array}$ & \multicolumn{4}{|c|}{ d. Bahan Pengisi } & 11.32 & 11.44 & 11.56 & 11.69 & 11.82 & 11.95 & 12.09 & \\
\hline \multicolumn{5}{|c|}{ Luas Total Permukaan Agregat $\left(\mathrm{m}^{2} / \mathrm{Kg}\right)$} & 11.26 & 11.69 & 11.75 & 11.80 & 11.86 & 11.92 & 11.61 & \\
\hline
\end{tabular}

Benda uji campuran latasir B standar dibuat berdasarkan perhitungan gradasi agregat campuran latasir B standar yang dihasilkan dari gradasi agregat kombinasi dan luas permukaan agregat total latasir B standar (Tabel 6).

\section{Karakteristik Marshall Campuran Latasir B Standar}

Hasil pemeriksaan campuran latasir B standar dengan menggunakan alat Marshall disajikan pada tabel 7.

Tabel 7. Hasil Pemeriksaan Campuran Latasir B Standar Dengan Alat Marshall

\begin{tabular}{ccccccc}
\hline \multirow{2}{*}{ No. Benda Uji } & \multicolumn{7}{c}{ Bacaan arloji Marshall Test } \\
\cline { 2 - 7 } & A & B & C & A & B & C \\
\cline { 2 - 7 } & 117 & 120 & 122 & 170 & 78 & 132 \\
1. & 110 & 95 & 90 & 160 & 185 & 125 \\
3. & 55 & 75 & 77 & 190 & 275 & 197 \\
4. & 74 & 71 & 69 & 385 & 230 & 315 \\
5. & 32 & 38 & 34 & 392 & 438 & 495 \\
6. & 21 & 22 & 17 & 610 & 620 & 522 \\
7. & 14 & 13 & 15 & 659 & 874 & 445 \\
\hline
\end{tabular}

Berdasarkan gradasi agregat kombinasi

(Tabel 7), sifat-sifat campuran latasir B standar campuran latasir B standar (tabel 6) dan hasil dirangkum sebagaimana pada tabel 8 . pemeriksaan campuran aspal dengan alat Marshall

Tabel 8. Rangkuman Sifat-Sifat Campuran Latasir B Standar

\begin{tabular}{ccccc}
\hline $\begin{array}{c}\text { Kadar } \\
\text { Bitumen } \\
(\%)\end{array}$ & $\begin{array}{c}\text { Marshal } \\
\text { Stability }(\mathrm{kg})\end{array}$ & $\begin{array}{c}\text { Marshal Quotient } \\
(\mathrm{kn} / \mathrm{mm})\end{array}$ & $\begin{array}{c}\text { Tebal Lapisan } \\
\text { Aspal Film }(\mathrm{mm})\end{array}$ & $\begin{array}{c}\text { Rongga } \\
\text { Udara }(\%)\end{array}$ \\
\hline $5.90 \%$ & 1854.8 & 14.36 & 9.51 & 14.96 \\
$6.90 \%$ & 1453.9 & 9.10 & 10.71 & 7.47 \\
$7.90 \%$ & 1262.6 & 5.61 & 12.24 & 7.20 \\
$8.90 \%$ & 1351.4 & 4.27 & 13.78 & 4.27 \\
$9.90 \%$ & 770.4 & 1.71 & 15.35 & 2.65 \\
$10.90 \%$ & 550.54 & 0.92 & 16.94 & 4.43 \\
$11.90 \%$ & 495.49 & 0.74 & 19.13 & 3.65 \\
\hline
\end{tabular}

Catatan: Nilai diatas diambil berdasarkan nilai rata-rata

Grafik hubungan kadar aspal dengan sifat-sifat campuran latasir B standar (Tabel 8) divisualisasikan pada gambar 2. Berdasarkan gambar 2, didapat kadar aspal optimum campuran latasir B standar 9.3\%, dengan kualitas campuran latasir B standar: marshall stability $905 \mathrm{~kg}$, marshall quotient 2.75 $\mathrm{KN} / \mathrm{mm}$, film thickness $14.4 \mathrm{~mm}$ dan volume air void $3.6 \%$.

\section{Campuran Latasir B dengan Abu Dasar Batubara}

Campuran nominal latasir B dengan abu dasar batubara sebagai pengganti sebagian agregat halus (pasir alam dan abu batu) ditentukan berdasarkan kadar aspal optimum campuran latasir B standar 9.3\%. Proporsi batu pecah dan bahan pengisi diambil secara konstan yaitu $11.08 \%$ dan $10.65 \%$, 
sedangkan proporsi agregat halus disesuaikan terhadap proporsi batu pecah, bahan pengisi dan kadar aspal agar total campuran 100\%, dengan demikian komposisi agregat halus adalah $68.97 \%$. Agregat pasir alam dan abu batu disesuaikan berdasar perbandingan hasil analisa saringan yaitu 45:55 (31.73\%:37.24\%). Adapun variasi kadar abu dasar batubara yang dicoba adalah $5 \%, 10 \%, 15 \%$,
$20 \%, 25 \%, 30 \%$ dan $35 \%$ dari total proporsi agregat halus. Penyesuaian proporsi campuran nominal latasir B dengan abu dasar batubara disajikan pada tabel 9. Sedangkan proporsi campuran agregat latasir B dengan abu dasar batubara disajikan pada tabel 10. Serta gadasi agregat kombinasi dan luas permukaan agregat total latasir B dengan abu dasar batubara yang disajikan pada tabel 11 .

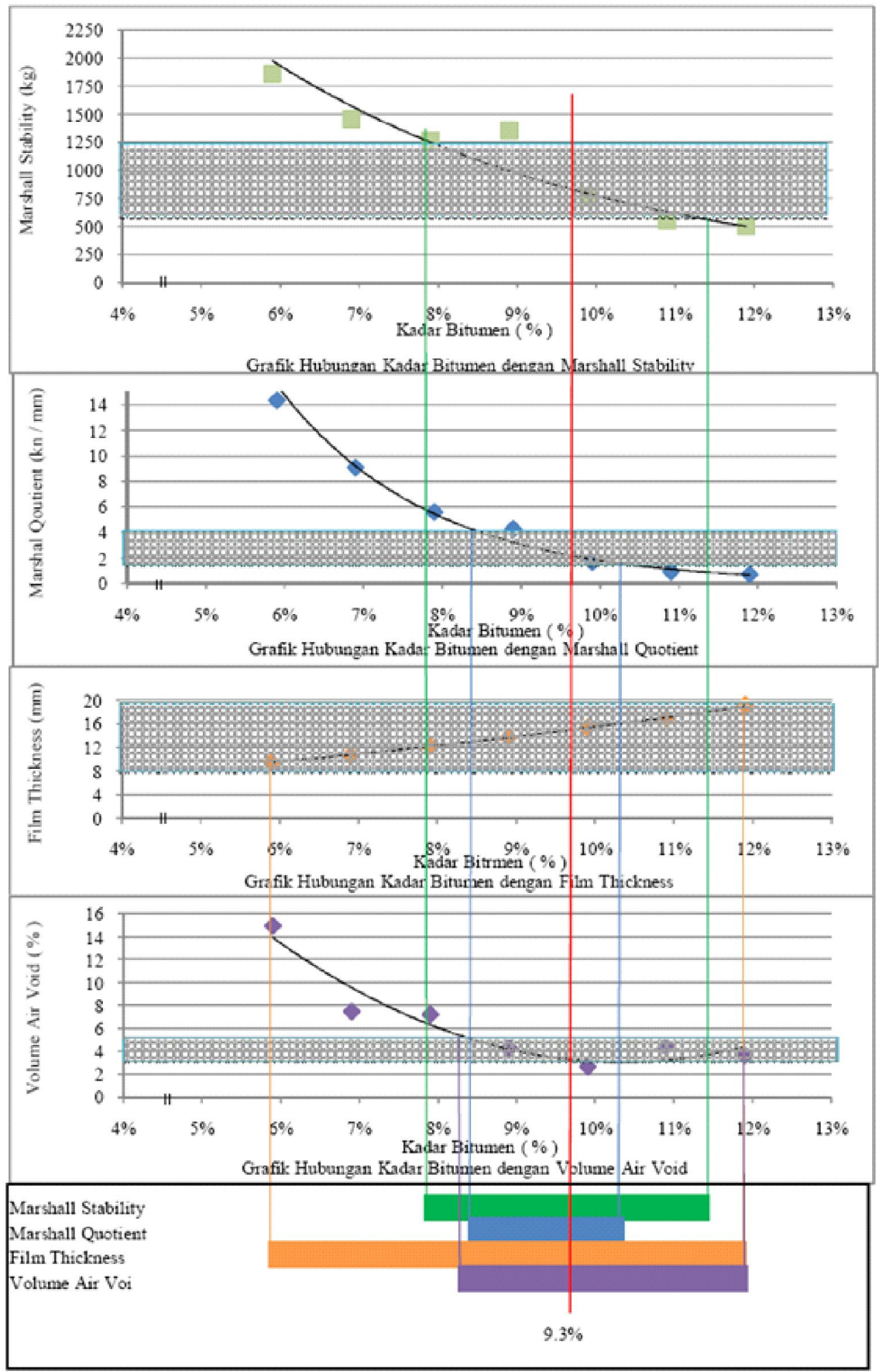

Gambar 2. Penentuan Kadar Aspal Optimum 
Tabel 9. Penyesuaian Proporsi Campuran Nominal Latasir B Dengan Abu Dasar Batubara

\begin{tabular}{|c|c|c|c|c|c|c|c|c|}
\hline \multirow[b]{3}{*}{ MATERIAL } & \multirow{3}{*}{$\begin{array}{c}\text { Campura } \\
\text { n } \\
\text { Nominal } \\
\text { Perhitun } \\
\text { gan }\end{array}$} & \multicolumn{7}{|c|}{ Proporsi Abu Dasar Batubara } \\
\hline & & 1 & 2 & 3 & 4 & 5 & 6 & 7 \\
\hline & & $5 \%$ & $10 \%$ & $15 \%$ & $20 \%$ & $25 \%$ & $30 \%$ & $35 \%$ \\
\hline Batu Pecah & 11.08 & 11.08 & 11.08 & 11.08 & 11.08 & 11.08 & 11.08 & 11.08 \\
\hline Abu Batu & 37.24 & 35.38 & 33.52 & 31.66 & 29.80 & 27.93 & 26.07 & 24.21 \\
\hline Pasir Alam & 31.73 & 30.14 & 28.55 & 26.97 & 25.38 & 23.79 & 22.21 & 20.62 \\
\hline $\begin{array}{c}\text { Abu Dasar } \\
\text { Batubara }\end{array}$ & 0.00 & 3.45 & 6.90 & 10.35 & 13.79 & 17.24 & 20.69 & 24.14 \\
\hline Bahan Pengisi & 10.65 & 10.65 & 10.65 & 10.65 & 10.65 & 10.65 & 10.65 & 10.65 \\
\hline Aspal (A) & 9.30 & 9.30 & 9.30 & 9.30 & 9.30 & 9.30 & 9.30 & 9.30 \\
\hline TOTAL & 100.00 & 100.0 & 100.0 & 100.0 & 100.0 & 100.0 & 100.0 & 100.0 \\
\hline & & 0 & 0 & 0 & 0 & & 0 & \\
\hline
\end{tabular}

Tabel 10. Proporsi Campuran Agregat Latasir B Dengan Abu Dasar Batubara

\begin{tabular}{cccccccc}
\hline & \multicolumn{7}{c}{ Proporsi Campuran Agregat (\%) } \\
\cline { 2 - 8 } MATERIAL & 1 & 2 & 3 & 4 & 5 & 6 & 7 \\
\cline { 2 - 8 } & $5 \%$ & $10 \%$ & $15 \%$ & $20 \%$ & $25 \%$ & $30 \%$ & $35 \%$ \\
\hline Batu Pecah & 12.22 & 12.22 & 12.22 & 12.22 & 12.22 & 12.22 & 12.22 \\
Abu Batu & 39.01 & 36.96 & 34.90 & 32.85 & 30.80 & 28.74 & 26.69 \\
Pasir Alam & 33.23 & 31.48 & 29.73 & 27.98 & 26.23 & 24.49 & 22.74 \\
Abu Dasar & 3.80 & 7.60 & 11.41 & 15.21 & 19.01 & 22.81 & 26.61 \\
Batubara & & & & & & & \\
Bahan Pengisi & 11.74 & 11.74 & 11.74 & 11.74 & 11.74 & 11.74 & 11.74 \\
\hline TOTAL & 100.00 & 100.00 & 100.00 & 100.00 & 100.00 & 100.00 & 100.00 \\
\hline
\end{tabular}

Tabel 11. Gradasi Agregat Kombinasi Dan Luas Permukaan Agregat Total Campuran Latasir B Dengan Abu Dasar Batubara

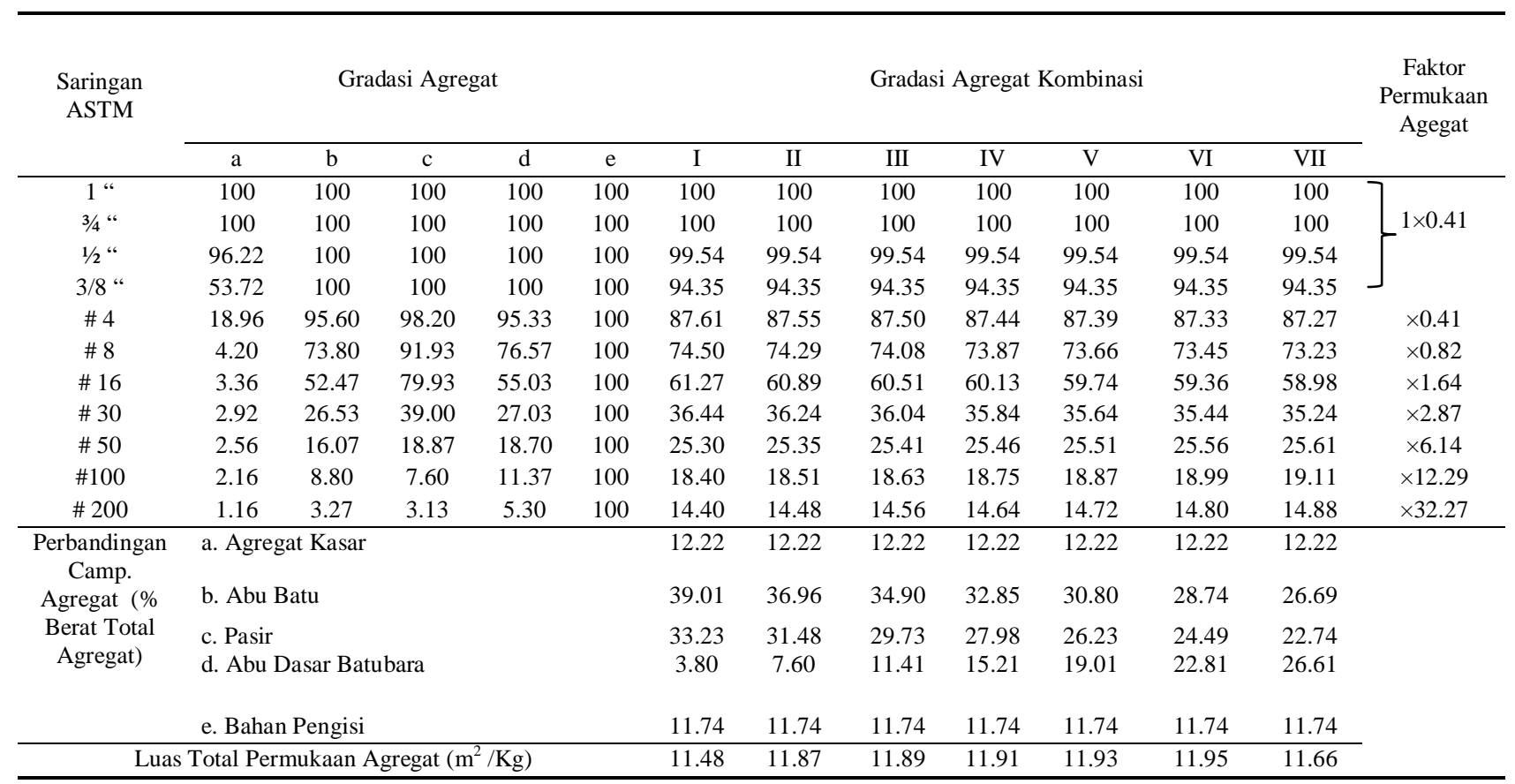

Benda uji dibuat berdasarkan perhitungan gradasi agregat campuran latasir B dengan abu dasar batubara yang dihasilkan dari gradasi agregat kombinasi dan luas permukaan agregat total dengan abu dasar batubara (Tabel 11). 
Karakteristik Marshall Campuran Latasir B Dengan Abu Dasar Batubara

Hasil pemeriksaan campuran latasir B dengan abu dasar batubara dengan menggunakan alat
Marshall disajikan pada tabel 12. Dan rangkuman sifat-sifat campuran latasir B dengan abu dasar batubara disajikan pada tabel 13 .

Tabel 12. Hasil Pemeriksaan Campuran Aspal Latasir B Dengan Abu Dasar Dengan Abu Dasar Batubara Dengan Alat Marshall

\begin{tabular}{ccccccc}
\hline \multirow{2}{*}{ No. Benda Uji } & \multicolumn{5}{c}{ Bacaan arloji Marshall Test } \\
\cline { 2 - 7 } & A & B & C & A & B & C \\
\cline { 2 - 6 } & 50 & 55 & 57 & 355 & 410 & 470 \\
1. & 50 & 54 & 58 & 425 & 430 & 270 \\
3. & 63 & 65 & 82 & 150 & 340 & 325 \\
4. & 68 & 88 & 86 & 305 & 260 & 288 \\
5. & 96 & 71 & 117 & 275 & 385 & 330 \\
6. & 67 & 115 & 100 & 425 & 205 & 310 \\
7. & 104 & 116 & 116 & 255 & 205 & 205 \\
\hline
\end{tabular}

Tabel 13. Rangkuman Rata-Rata Sifat-Sifat Campuran Latasir B Dengan Abu Dasar Batubara

\begin{tabular}{ccccc}
\hline $\begin{array}{c}\text { Kadar Abu } \\
\text { Dasar Batubara } \\
(\%)\end{array}$ & $\begin{array}{c}\text { Marshal } \\
\text { Stability }(\mathrm{kg})\end{array}$ & $\begin{array}{c}\text { Marshal } \\
\text { Quotient } \\
(\mathrm{kn} / \mathrm{mm})\end{array}$ & $\begin{array}{c}\text { Tebal Lapisan } \\
\text { Aspal Film (mm) }\end{array}$ & $\begin{array}{c}\text { Rongga Udara } \\
(\%)\end{array}$ \\
\hline $5.00 \%$ & 1071.2 & 2.55 & 14.85 & 0.07 \\
$10.00 \%$ & 1039.7 & 2.72 & 14.39 & 0.36 \\
$15.00 \%$ & 1230.3 & 4.44 & 14.38 & 2.46 \\
$20.00 \%$ & 1329.3 & 4.58 & 14.37 & 4.24 \\
$25.00 \%$ & 1461.3 & 4.34 & 14.36 & 8.09 \\
$30.00 \%$ & 1415.20 & 4.43 & 14.35 & 9.71 \\
$35.00 \%$ & 1503.96 & 6.65 & 14.72 & 11.16 \\
\hline
\end{tabular}

Campuran latasir B dengan abu dasar batubara sebagai pengganti sebagian agregat halus pada kadar abu dasar batubara 5\%-18.5\% menghasilkan Marshall Stability 1071.2-1250 kg, sedangkan kadar abu dasar batubara $5.8 \%-19.5 \%$ menghasilkan Marshall Quotient 2.75-4 KN/mm, dan kadar abu dasar batubara 27.6\%-35\% menghasilkan Film Thickness 14.40-14.72 mm serta pada kadar abu dasar batubara 15.08-20.01\% menghasilkan Volume Air Void 3-5\%.

Tabel 14. Karakteristik Marshall Campuran Latasir B dengan Variasi proporsi Abu Dasar Batubara

\begin{tabular}{|c|c|c|c|c|c|c|c|c|}
\hline \multirow{2}{*}{$\begin{array}{c}\text { Karakteristik } \\
\text { Marshall }\end{array}$} & \multicolumn{8}{|c|}{ Proporsi Abu Dasar Batubara } \\
\hline & $0 \%$ & $5 \%$ & $10 \%$ & $15 \%$ & $20 \%$ & $25 \%$ & $30 \%$ & $35 \%$ \\
\hline $\begin{array}{c}\text { Marshall Stability } \\
(\mathrm{kg})\end{array}$ & 905 & 1071.2 & 1039.7 & 1230.3 & 1329.3 & 1461.3 & 1415.20 & 1503.96 \\
\hline $\begin{array}{l}\text { Marshall Quotient } \\
(\mathrm{kN} / \mathrm{mm})\end{array}$ & 2.75 & 2.55 & 2.72 & 4.44 & 4.58 & 4.34 & 4.43 & 6.65 \\
\hline ilm Thickness (mm) & 14.4 & 14.85 & 14.39 & 14.38 & 14.37 & 14.36 & 14.35 & 14.72 \\
\hline 'olume Air Void (\%) & 3.6 & 0.07 & 0.36 & 2.46 & 4.24 & 8.09 & 9.71 & 11.16 \\
\hline
\end{tabular}

Catatan: Kadar Aspal 9.3\%

Tabel 15. Perbandingan Karakteristik Marshall dan Bahan Campuran Latasir B Standar dengan Campuran Latasir B Dengan Abu Dasar Batubara

\begin{tabular}{lcc}
\hline \multicolumn{1}{c}{ Jenis Campuran } & $\begin{array}{c}\text { Campuran Latasir B } \\
\text { Standar }\end{array}$ & $\begin{array}{c}\text { Campuran Latasir B Dengan } \\
\text { Abu Dasar Batubara }\end{array}$ \\
\hline Karakteristik Marshall: & & \\
- Marshall Stability & $905 \mathrm{~kg}$ & $1230.3 \mathrm{~kg}$ \\
- Marshall Quotient & $2.75 \mathrm{kN} / \mathrm{mm}$ & $3.8 \mathrm{kN} / \mathrm{mm}$ \\
- Film Thickness & $14.4 \mathrm{~mm}$ & $14.4 \mathrm{~mm}$ \\
- Volume Air Void & $3.6 \%$ & $3.6 \%$ \\
\hline
\end{tabular}


Bahan Campuran Aspal:

- Batu pecah

$11.08 \%$

$11.08 \%$

- Abu batu

$37.24 \%$

$27.96 \%$

- Pasir alam

$31.73 \%$

$23.81 \%$

- Abu dasar batubara

$0 \%$

$17.2 \%$

- Bahan pengisi

$10.65 \%$

$10.65 \%$

- Kadar aspal

$9.3 \%$

$9.3 \%$



Gambar 3. Penentuan Kadar Abu Dasar Batubara Optimum 
Kadar aspal optimum pada campuran latasir B standar adalah 9.3\% sedangkan kadar abu dasar batubara optimum pada campuran latasir B dengan abu dasar batubara sebagai pengganti sebagian agregat halus adalah $17.2 \%$. Berikut adalah perbandingan kedua campuran tersebut baik dari segi karakteristik Marshall maupun bahan campuran aspalnya.

\section{KESIMPULAN DAN SARAN}

- Adanya penggantian sebagian agregat halus dengan abu dasar batubara secara umum berpengaruh berupa flaktuasi karakteristik marshall campuran Latasir B.

- Karakteristik Marshall campuran aspal latasir B dengan abu dasar batubara (marshall stability $1230.3 \mathrm{~kg}$, marshall quotient $3.8 \mathrm{kN} /$ $\mathrm{mm}$, film thickness $14.4 \mathrm{~mm}$ dan volume air void $3.6 \%$ ) terbaik yaitu pada kadar abu dasar batubara $17.2 \%$.

\section{DAFTAR PUSTAKA}

Muhammad, R, 2012, Karakteristik Campuran Aspal Dengan Agregat, [http://em ridho.blogspot.com/2012/01/laporanpraktikum-karakteristik.html?m=1]

Patrick, Andarias, 2003, Pengaruh Penggunaan Bottom Ash Terhadap Karakteristik Campuran Aspal Beton, Jurusan Teknik Sipil, Fakultas Teknik Universitas Kristen Petra

SNI 03-1737-1989, Pelaksanaan lapis campuran beraspal panas.

SNI 03-1737-1989, Pelaksanaan lapis campuran beraspal.

SNI 03-6749-2002, Spesifikasi bahan lapis tipis aspal pasir (Latasir).

SNI 03-6819-2002, Spesifikasi agregat halus untuk campuran perkerasan beraspal.

SNI 03-6723-2002, Spesifikasi bahan pengisi untuk campuran beraspal.

Sukirman, S, 1999, Perkerasan Lentur Jalan Raya, Penerbit Nova, Bandung.

Sukirman, S, 2003, Beton Aspal campuran Panas, Penerbit Nova, Bandung. 